\title{
The Potential Protective Role of Hesperidin Against Capecitabine- Induced Corneal Toxicity in Adult Male Albino Rat. Light and Electron Microscopic Study
}

\author{
Original \\ Article \\ Walaa M. Elwan and Amira A. Kassab \\ Department of Histology, Faculty of Medicine, Tanta University, Tanta, Egypt
}

\begin{abstract}
Background: Capecitabine is a chemotherapeutic agent widely used for the treatment of malignancies. Ocular disorders have been reported with capecitabine therapy. Hesperidin is a naturally occurring compound derived mainly from citrus fruits and has a wide range of pharmacological activities and a proposed role in combating many ocular diseases.

Aim: To evaluate the potential protective role of hesperidin against the corneal toxicity caused by capecitabine in adult male albino rats.

Material and Methods: Thirty-six adult male albino rats were divided into four equal groups; control group, hesperidintreated group (50 mg/kg), capecitabine-treated group (40 mg/kg), and combination-treated "capecitabine and hesperidintreated" group. Animals were orally administered once daily for one month. Specimens from the cornea were processed for light and electron microscopy. Immunohistochemical study was performed using antibodies against p53.

Results: Specimens from capecitabine-treated animals showed significant decrease of epithelial thickness. The corneal epithelial cells showed nuclear alteration and vacuolated cytoplasm. The stromal collagen fibers were irregularlyarranged and widely separated with neovascularization and mononuclear cellular infiltration. Ultrastructurally, focal widening of the intercellular spaces, partial loss of desmosomal junctions and swollen mitochondria were observed. The immunohistochemical study showed a significant increase in p53 immunoreaction. In contrast, minimal changes were observed in rats treated concomitantly with both capecitabine and hesperidin, with a non significant increase in the immunoreactions.

Conclusion: Capecitabine induced structural changes in cornea of adult albino rat that could be ameliorated by concomitant treatment with hesperidin.
\end{abstract}

Key Words: Capecitabine, cornea, electron microscopy, hesperidin, P53.

Revised: 14 October 2016, Accepted: 06 June 2017

Corresponding Author: Walaa M. Elwan, Department of Histology, Faculty of Medicine, Tanta University, Tanta, Egypt , Tel.: 0020-10 0357 3258, E-mail: w.elwan@yahoo.com

ISSN: 1110-0559, 2017, Vol. 40, No 2

\section{INTRODUCTION}

The most widely used chemotherapeutic drugs associate with broad spectrum organ toxicities as bone marrow suppression, cardiac, pulmonary, gastrointestinal, hepatic, and renal toxicities, but the eye was considered a protected site ${ }^{[1]}$. Nonetheless, the ocular system is highly sensitive to toxic substances ${ }^{[2,3]}$, and the systemic druginduced ocular side effects have been increased with the increasing numbers of new drugs being introduced ${ }^{[4]}$.

Ocular complications such as conjunctivitis, keratitis, cataract, macular edema, retinopathy and optic neuropathy have been associated with a variety of chemotherapeutic agents such as alkylating agents, anti-metabolites, taxanes and platinum agents ${ }^{[5,6]}$.
Capecitabine (a fluoropyrimidine carbamate) is a proanticancer and immunosuppressive drug. Inside the body, it is enzymatically converted into 5-fluorouracil (5-FU) with high tumor selectivity ${ }^{[7,8]}$. The improved tolerability and efficacy of capecitabine compared with intravenous 5- FU, in addition to its oral route of administration make it the best choice for different classes of carcinomas as colorectal, breast and pancreatic carcinomas ${ }^{[9-11]}$. Diarrhea, hand-foot syndrome and oromandibular dystonia are frequent complications for capecitabine treatment ${ }^{[12-}{ }^{14]}$. Moreover, ocular complications such as ocular irritation, decreased vision and corneal deposits have been associated with capecitabine therapy ${ }^{[15]}$.

Flavonoids are naturally occurring polyphenolic compounds synthesized by plants and having many 
pharmacological activities. They act as powerful free radical scavengers protecting the human body through the $\mathrm{OH}$ group present in their molecular structure. They include six major classes: flavonols, flavones, flavanones, catechins, anthocyanidins and isoflavones ${ }^{(16)}$.

Hesperidin is a natural inexpensive flavanone glycoside present in large quantities in citrus fruits like orange and lemon. It plays an important role in prevention of many diseases due to its anti-oxidant, anti-inflammatory, anticarcinogenic, anti-ulcer activities ${ }^{[17,18]}$, in addition to its antimelanogenic and neuroprotective effects ${ }^{[19,20]}$. Moreover, it has anti-microbial, anti-allergic, immunomodulatory, hepatoprotective, and nephroprotective effects ${ }^{[21-23]}$. The ameliorative role of hesperidin against tissue toxicities induced by various chemotherapeutic agents as doxorubicin, methotrexate, and cisplatin has been reported ${ }^{[24-26]}$.

Previous studies illustrated the therapeutic role of hesperidin in various ocular disorders such as diabetic retinopathy, diabetic macular edema in addition to its anti-cataractogenic effects ${ }^{[27]}$. Subsequently, we aimed to evaluate the potential protective role of hesperidin against the corneal toxicity caused by capecitabine in rats using different histological and immunohistochemical techniques.

\section{MATERIALS AND METHODS:}

Thirty-six adult male albino rats (180- 200 grams) were used in this study. They were kept in clean properly ventilated cages under similar environmental conditions. One week prior to the experiment, all rats were kept in clean properly ventilated cages for acclimatization. A commercial balanced diet and tap water were provided throughout the experiment, with free access to food and water. The animals were kept on a 12-hour light/12-hour dark cycle before and throughout the study period. The experiment was approved by the local ethical Committee of Faculty of Medicine, Tanta University. The animals were divided into four equal groups ( 9 animals, each):

Group I (control group): It was subdivided into three equal subgroups; subgroup Ia received no treatment. Subgroup Ib received $0.5 \mathrm{ml}$ of $0.25 \%$ solution of sodium carboxymethyl cellulose (the vehicle for hesperidin) orally once daily for one month. Subgroup Ic received $0.4 \mathrm{ml}$ of normal saline solution (the vehicle for capecitabine) orally once daily for one month.

Group II (Hesperidin-treated group): Rats of this group were administered $0.5 \mathrm{ml}$ of freshly prepared hesperidin $(50 \mathrm{mg} / \mathrm{kg})(28-30)$ dissolved in $0.25 \%$ solution of sodium carboxymethyl cellulose (CMC) orally by a gastric tube once daily for one month. Hesperidin was purchased from Sigma-Aldrich, St Louis, MO, USA (cat\# H5254).

Group III (Capecitabine-treated group): Rats of this group were administered $40 \mathrm{mg} / \mathrm{kg}$ of capecitabine dissolved in $0.4 \mathrm{ml}$ of normal saline solution orally by a gastric tube once daily for one month. The therapeutic dose of this drug for rat was calculated according to Paget and Barnes $^{[31]}$. The chosen dose was nearly similar to the human effective therapeutic dose (ETD). Capecitabine (Xeloda) was purchased from Roche Company for pharmaceuticals (Cairo, Egypt) in the form of tablets containing $500 \mathrm{mg}$ each.

Group IV (Capecitabine- \& Hesperidin-treated group): Rats of this group were concomitantly administered both hesperidin and capecitabine (at the same doses and duration as in groups II \&III, respectively).

At the end of the experiment, all rats were anesthetized by an intraperitoneal injection of pentobarbital $(50 \mathrm{mg} /$ $\mathrm{kg}$ body weight ${ }^{[32]}$. Then, the eyes were enucleated and the globes were placed in Karnovsky fixative (2\% paraformaldehyde and $2.5 \%$ glutaraldehyde) for 24 hours. The cornea was excised from the remainder of the globe and processed for histological and immunohistochemical study.

For light microscopy: The specimens were immersed in $10 \%$ neutral-buffered formalin, washed, dehydrated, cleared and then embedded in paraffin. Sections of $5 \mu \mathrm{m}$ thickness were stained with haematoxylin and eosin $(\mathrm{H} \& \mathrm{E})^{[33]}$.

For immunohistochemistry: $5 \mu \mathrm{m}$ thick sections were dewaxed, rehydrated, and washed with phosphate buffered saline (PBS). Then, the sections were incubated overnight in a humid chamber with the primary antibody (Rabbit polyclonal anti-rat antibody against p53 (Abcam, ab131442; Cambridge, Massachusetts, USA). The sections were incubated with diluted p53 primary antibody $(1: 100)$ in PBS overnight at $4^{\circ} \mathrm{C}$. Thereafter, it was washed in PBS buffer, and co-incubated with biotinylated secondary antibody (Dako North America, Inc., CA, USA) for an hour at room temperature was performed. Streptavidin peroxidase was added for 10 minutes and rinsed three times in PBS. The immunoreactivity was visualized using 3, 3'diaminobenzidine (DAB)-hydrogen peroxide as a chromogen. Sections were counterstained with Mayer's haematoxylin. The negative control sections were prepared by excluding the primary antibodies ${ }^{[34]}$. Positive controls for p53 were MDA and JK cell extracts, HeLa cells and Human breast carcinoma tissue. The p53 immunostained corneal sections were considered positive upon expressing clear evident brown cytoplasmic and/or nuclear coloration.

For transmission electron microscopy: The specimens were fixed by immersion in $2.5 \%$ phosphate buffered glutaraldehyde, processed and then embedded in epoxy resin by routine protocol. Semithin sections $(1 \mu \mathrm{m}$ thick) were obtained and stained with $1 \%$ toluidine blue and examined by light microscope. Ultrathin sections $(80-90 \mathrm{~nm})$ were stained with uranyl acetate and lead citrate to be examined by JEOL electron microscope 
at $80 \mathrm{KV}$ in E.M unit, Faculty of Medicine, Tanta University ${ }^{[35]}$.

\section{Morphometric study}

Image analysis system (Leica Qwin $500 \mathrm{C}$ Image analyzer computer system (Leica Imaging System LTD., Cambridge, England) at (Central Research Lab, Faculty of Medicine, Tanta University, Egypt) was used to measure:

1) The mean thickness of the corneal epithelium using H\&E stained sections. Ten different non-overlapping randomly-selected fields at magnification of 100 were examined for each slide.

2) The mean color intensity of p53 positive immunohistochemical reaction (in DAB stained sections). Ten different non-overlapping randomly-selected fields at magnification of 400 were examined for each slide.

\section{Statistical analysis}

Data were analyzed by using one-way analysis of variance (ANOVA) followed by Tukey's test for comparison between the groups using statistical package for social sciences statistical analysis software (version 11.5; SPSS Inc., Chicago, Illinois, USA). All values were expressed as mean \pm standard deviation. Differences were regarded as significant if probability value $p<0.05$ and highly significant if $p<0.001^{[36]}$.

\section{RESULTS}

No deaths occur throughout the experimental period.

\section{Light microscopic findings}

Group I (control group): All control subgroups showed the same histological findings. H\&E-stained sections of this group showed the characteristic histological structure of the cornea that was formed of five organized layers. The stratified squamous non keratinized epithelial layer appeared with its basal columnar cells, intermediate polygonal cells and superficial squamous cells. The corneal epithelium appeared resting on a uniform basement membrane underneath it was the Bowman's layer. The layer of corneal stroma (substantia propria) contained regularly arranged lamellae of collagen fibers that were parallel to each other. Flattened fibrocytes (keratocytes) were located between the lamellae of collagen fibers. Descemet's membrane layer appeared beneath the stroma and was covered by the inner endothelial layer (Fig. 1).

Group II (Hesperidin-treated group): It showed the same histological structure as the control group.

Group III (Capecitabine-treated group): Examination of H\&E-stained sections of capecitabinetreated rats showed multifocal structural changes. The epithelium was mostly affected and focal areas of epithelial separation and desquamation were noticed (Fig. 2). Some epithelial cells showed pale vacuolated cytoplasm and deeply stained nuclei (Fig. 3). In addition, apparent decrease in epithelial thickness was observed in some focal areas (Fig. 4). Disruption and wide separation of the stromal fibers was observed (Figs. 3, 4). Moreover, the anterior region of stroma close to the surface epithelium showed a neovascularization and inflammatory cellular infiltration (Figs. 2, 3). In addition, some endothelial cells showed pale vacuolated cytoplasm (Fig. 4).

Group IV (capecitabine \& hesperidin-treated group): H\&E stained sections of this group revealed results almost similar to that of the control group. Nevertheless, cytoplasmic vacuolation was noticed in few epithelial cells (Fig. 5).

\section{Immunohistochemical results:}

P53-immunostained corneal sections of the control group I as well as the hesperidin-treated group II revealed moderate positive immunoreaction for $\mathrm{p} 53$ in corneal epithelial cells (Fig. 6a). However, the stromal keratocytes and endothelium were negative for this reaction (Fig. 6b). In capecitabine-treated group III, strong positive cytoplasmic and/or nuclear p53 immunoreactions was observed in many corneal epithelial cells, stromal keratocytes and endothelium (Figs. 7a, and 7b), while in capecitabine $\&$ hesperidin-treated group IV, moderate positive immunoreaction for p53 was detected in many corneal epithelial cells, and weak positive p53immunoreaction was observed in the stromal keratocytes and endothelium (Figs. 8a, 8b).

\section{Electron microscopic results}

\section{Group I (control group):}

Ultrathin sections revealed normal histological structure of the cornea. The corneal epithelium appeared to be formed of a basal layer of columnar cells with oval nuclei. The cytoplasm contained a profile of RER and mitochondria. The basal surface of these epithelial cells was in contact with the basement membrane by electrondense dotted hemidesmosomes. The intermediate cell layer were about 34- layers of polygonal cells having rounded nuclei. The squamous cells appeared superficially arranged in one or two layers and had flat nuclei. All these epithelial cells were attached together with numerous electron-dense desmosomes and had narrow intercellular spaces (Figs. 10, 11). The stroma composed of regular collagen fiber lamellae arranged parallel to the corneal surface. The keratocytes were spindle-shaped cells squeezed in-between these collagen lamellae, and contained electron-dense oval nuclei and scanty cytoplasm containing RER and lysosomes. Next to the stroma, a thick homogenous non-cellular electrondense lamina, Descemet's membrane, was found and appeared lined by a single flattened endothelial cell layer. The endothelial cells contained electron-dense flat 
elongated nuclei and a scanty cytoplasm with RER profile (Figs. 12, 13).

Group II (Hesperidin-treated group): Electron microscopic findings of this group were similar to control group.

Group III (Capecitabine-treated group): Examination of this group revealed marked ultrastructural changes in the cornea. The corneal epithelium showed focal separation and widening of the intercellular spaces with partial loss of desmosomal junctions (Fig. 14). Cytoplasmic vacuolation as well as swollen mitochondria with disrupted cristae were found affecting most epithelial cell layers (Figs. 15-18). Some nuclei appeared with irregular outlines (Figs. 17, 18), and others were shrunken and hyperchromatic (Figs. 16, 17). Concerning the stroma, disorganized collagen fibers were observed in some specimens. In addition, cytoplasmic vacuolation and dilated RER were observed in some keratocytes (Fig. 19). Another observation was the appearance of multiple variable sized vacuoles in the cytoplasm of some endothelial cells (Fig. 20).

Group IV: (capecitabine \& hesperidin-treated group): Electron microscopic findings of this group were similar to control group. Nevertheless, mild cytoplasmic vacuolation and few swollen mitochondria were observed in few epithelial basal cells (Fig. 21). Focal cytoplasmic vacuolation was observed in few intermediate and superficial cells (Fig. 22). The stroma appeared almost normal (Fig. 23). Few small vacuoles were observed in few endothelial cells (Fig. 24).

\section{Morphometric and statistical results}

The mean color intensity of p53 positive immunoreaction in the capecitabine-treated group (group III) showed a significant increase (54.8 \pm 10.3$)$ compared to the control group (28.64 \pm 5.42$)$, while capecitabine and hesperidin-treated group (group IV) showed a nonsignificant increase $(32.76 \pm 2.46)$ compared to the control (Table 1 \& Histogram 1).

The mean thickness of the corneal epithelium showed a highly significant decrease $(5.58 \pm 0.56)$ in the capecitabine-treated group (Group III) compared to the control group $(10.12 \pm 0.90)$. Moreover, capecitabine $\&$ hesperidin-treated group (Group IV) showed a nonsignificant decrease $(9.35 \pm 0.94)$ compared to the control (Table $1 \&$ Histogram 2).

Table 1: Morphometeric analysis of the corneal specimens of all groups

\begin{tabular}{lcccc}
\hline Parameters & Group I & Group II & Group III & Group IV \\
\hline $\begin{array}{l}\text { P53 mean color } \\
\text { intensity }\end{array}$ & $28.64 \pm 5.42$ & $28.68 \pm 4.87$ & $54.8 \pm 10.3^{*}$ & $32.76 \pm 2.46$ \\
$\begin{array}{l}\text { Mean thickness } \\
\text { of the corneal } \\
\text { epithelium }\end{array}$ & $10.12 \pm 0.90$ & $10.0 \pm 0.95$ & $5.58 \pm 0.56^{*}$ & $9.35 \pm 0.94$ \\
\hline
\end{tabular}

Data are expressed as mean \pm standard deviation, ${ }^{*} P<0.05$ is significant versus control.

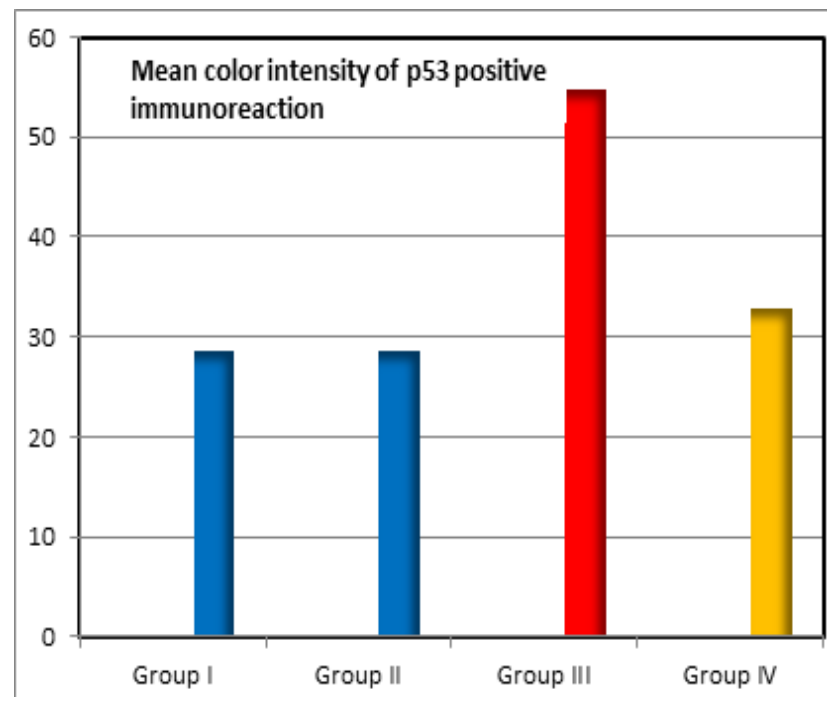

Histogram 1: The mean color intensity of p53 positive immunoreaction in all groups.

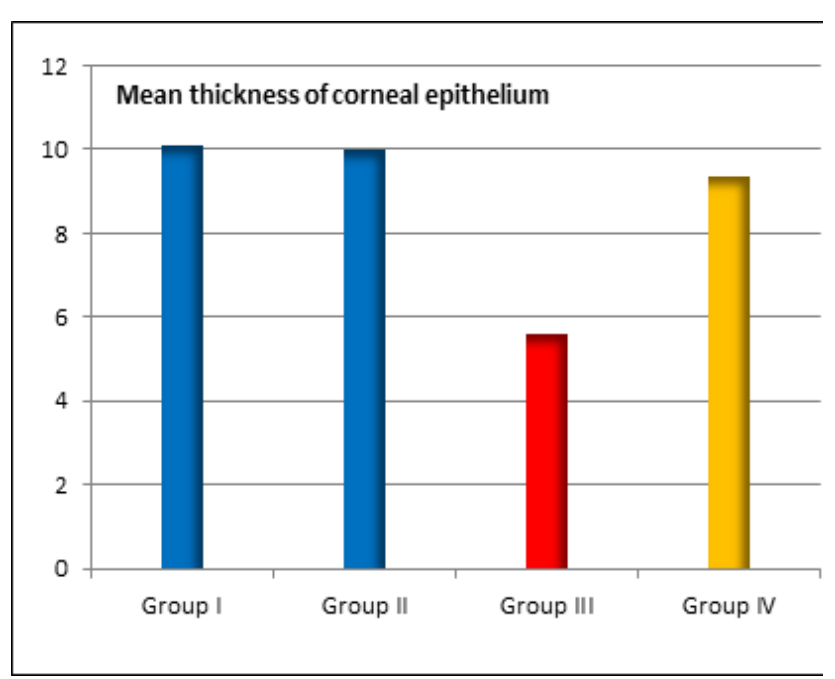

Histogram 2: The mean thickness of the corneal epithelium in all groups. 


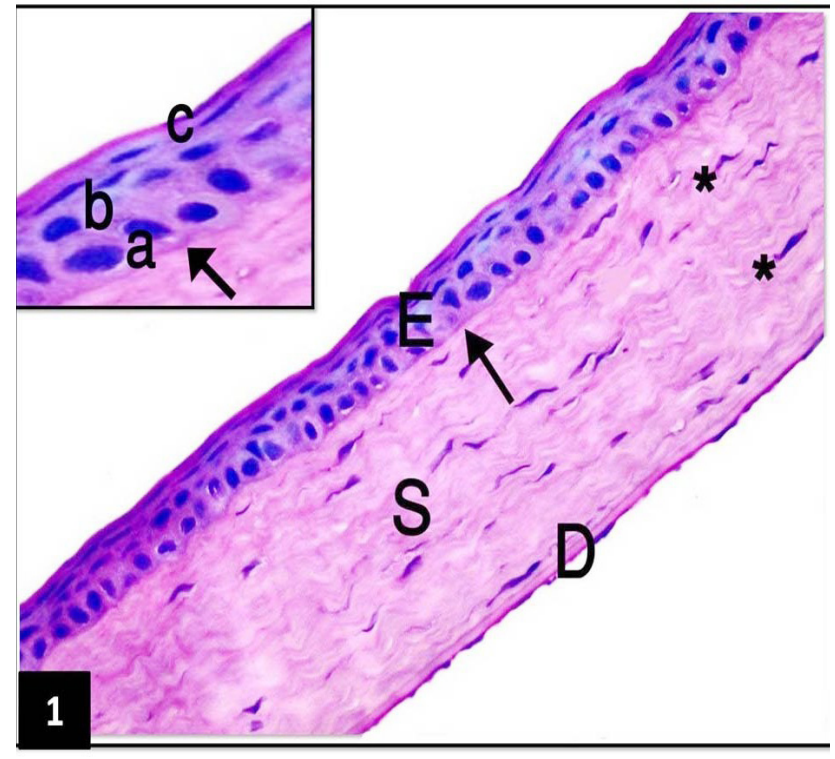

Fig. 1: A photomicrograph of a section in the cornea of an adult male albino rat from the control group showing a stratified squamous nonkeratinized epithelium (E) with an underlying Bowman's membrane (arrow). The stroma (S) contains regularly organized collagen bundles with keratocytes (asterisks) squeezed in-between. Descemet's membrane and single flattened endothelial cell layer (D) can be also seen. The inset show a higher magnification of the epithelium with its basal columnar cells (a), intermediate polygonal cells (b) and superficial squamous cells (c) supported by Bowman's membrane (arrow). (H\&E X 400, InsetX1000).

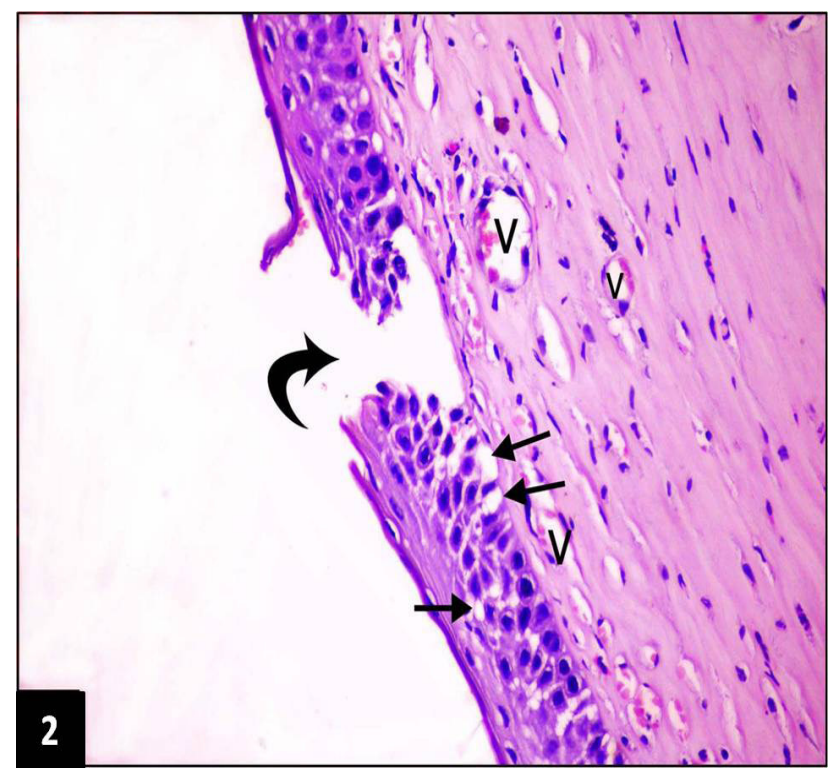

Fig. 2: A photomicrograph of a section in the cornea of an adult male albino rat from the capecitabine-treated group (group III) showing focal separation and desquamation of the corneal epithelium (curved arrow). Notice the vacuolated cytoplasm of the epithelial cells (arrows). A neovascularization (V) of the superficial stroma can be also seen.

(H\&E X 400).

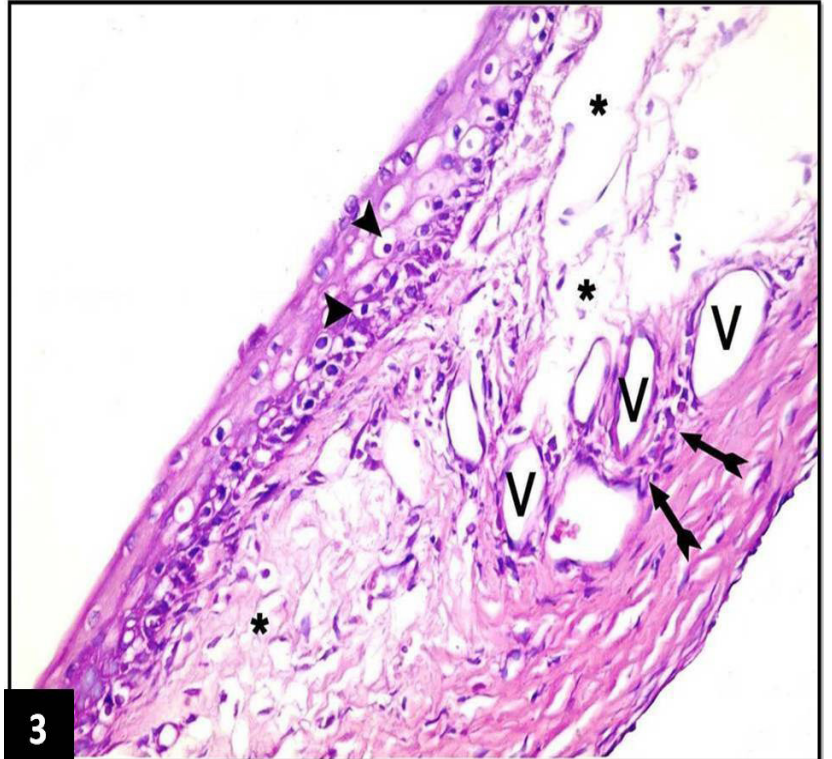

Fig. 3: A photomicrograph of a section in the cornea of an adult male albino rat from the capecitabine-treated group (group III) showing disorganized epithelial cells having deeply stained nuclei surrounded by vacuolated cytoplasm (arrow heads). Notice the disorganized widely separated stromal fibers (asterisks), neovascularization (V) and mononuclear cellular infiltration (notched arrows).

(H\&E X 400).

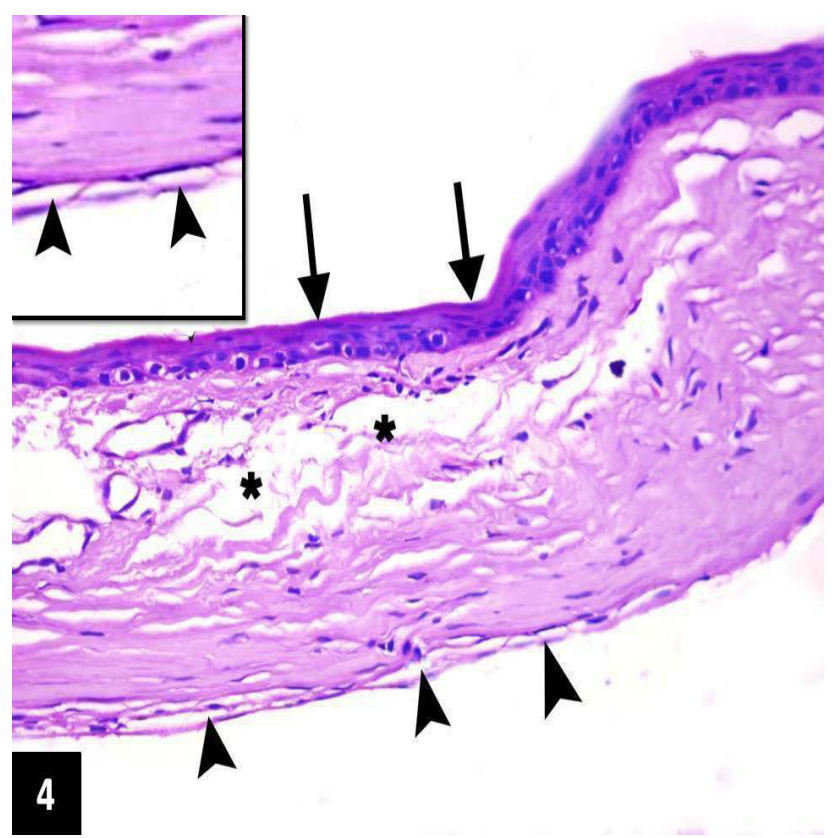

Fig. 4: A photomicrograph of a section in the cornea of an adult male albino rat from the capecitabine-treated group (group III) showing irregularly arranged epithelium with apparent focal decrease in its thickness (arrows). The stromal fibers are widely separated (asterisks). Notice the vacuolated cytoplasm of the endothelial cells (arrow heads). The inset shows a higher magnification of the vacuolated endothelial cells.

(H\&E X 400, InsetX1000). 


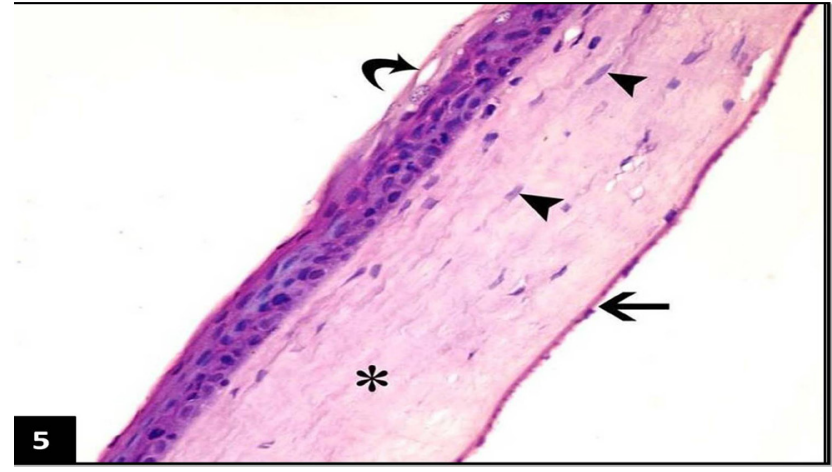

Fig. 5: A photomicrograph of a section in the cornea of an adult male albino rat from the capecitabine\& hesperidin-treated group (group IV) showing regularly organized keratocytes (arrow heads) and stromal fibers (asterisk) with narrow spaces in-between. The Descemet's membrane is lined by flattened endothelial cells (arrow). A vacuolated epithelial cell (curved arrow) can be seen

(H\&E X 400).

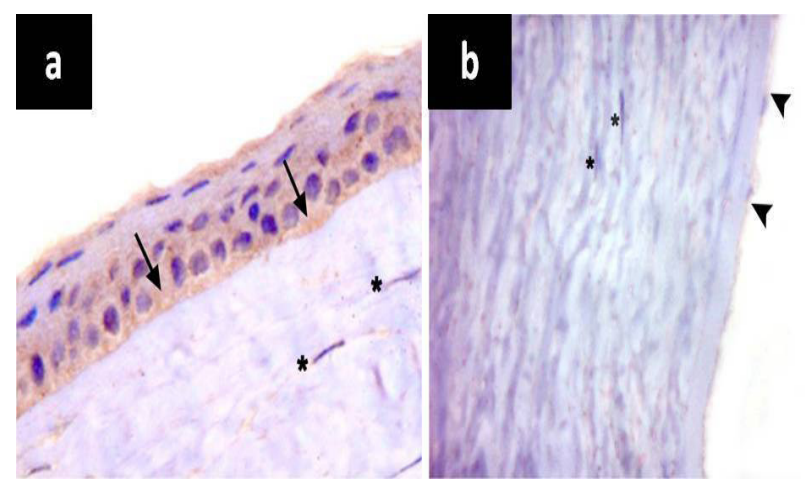

Fig. 6: A photomicrograph of a section in the cornea of an adult male albino rat from the control group. (a) Showing moderate positive cytoplasmic immunoreaction for p53 in the corneal epithelial cells (arrows). The stromal keratocytes (asterisks) showed negative p53 immunoreaction. (B) Showing negative p53 immunoreaction in the stromal keratocytes (asterisks) and endothelial cells (arrow heads)

(P53 immunostaining X 1000).

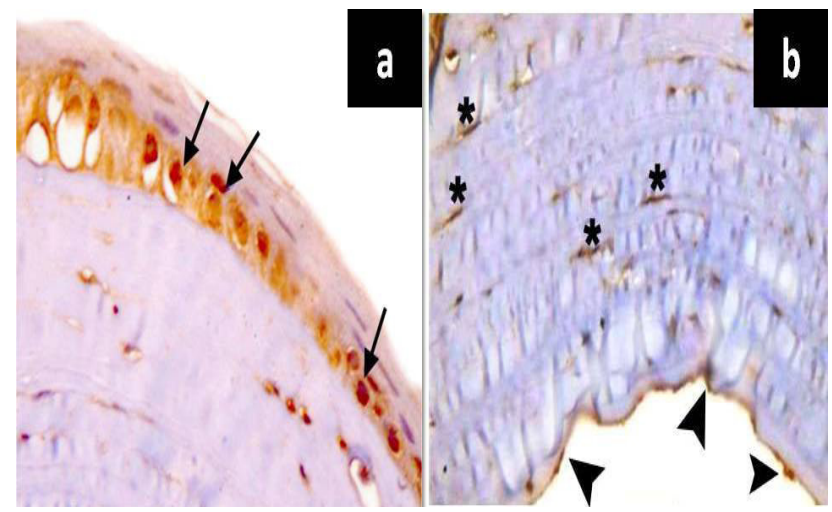

Fig. 7: A photomicrograph of a section in the cornea of an adult male albino rat from the capecitabine-treated group (group III). (a) Showing strong positive cytoplasmic and/ or nuclear immunoreaction for p53 in many epithelial cells (arrows) (b) Showing strong positive cytoplasmic and/or nuclear immunoreaction for p53 in many keratocytes (asterisks) and endothelial cells (arrow heads). (P53 immunostaining X 1000).

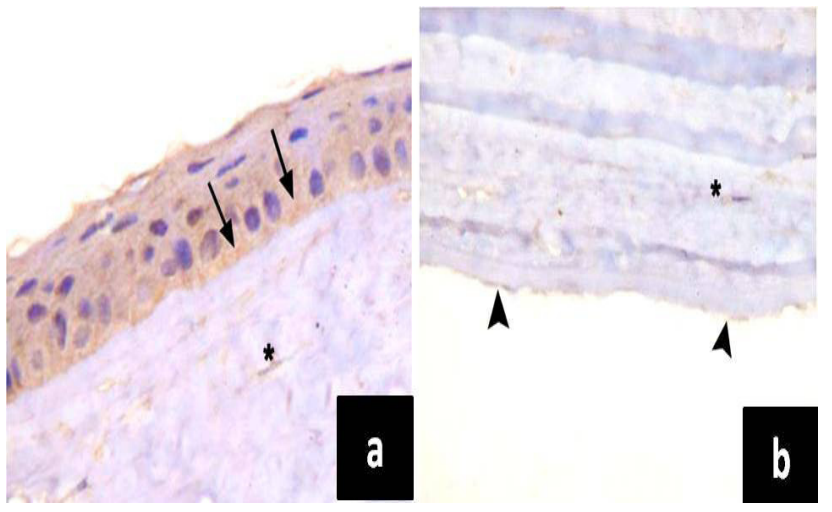

Fig. 8: A photomicrograph of a section in the cornea of an adult male albino rat from the capecitabine $\&$ hesperidin-treated group (group IV). (a) Showing moderate positive cytoplasmic immunoreaction for $\mathrm{p} 53$ in many epithelial cells (arrows). A weak immunoreaction can be seen in a stromal keratocyte (asterisk). (b) Showing weak positive cytoplasmic immunoreaction for p53 in many endothelial cells (arrow heads). A keratocyte can be seen having weak positive p53-immunoreaction (asterisk). (P53 immunostaining X 1000).

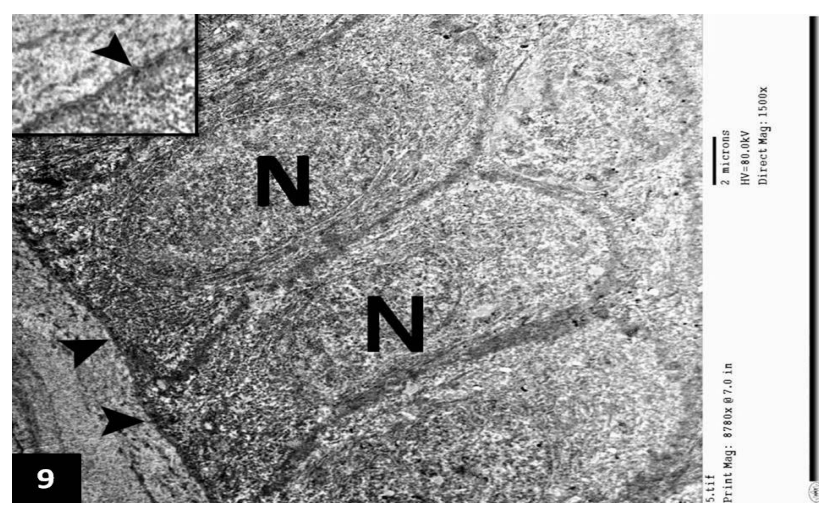

Fig. 9: An electron micrograph of rat cornea from the control group showing basal columnar cells of corneal epithelium having oval nuclei $(\mathrm{N})$ and attached to the basal lamina with numerous electron-dense dotted hemidesmosomes (arrow head). The inset shows a higher magnification of hemidesmosomes (TEM X 8780, Inset X 17560).

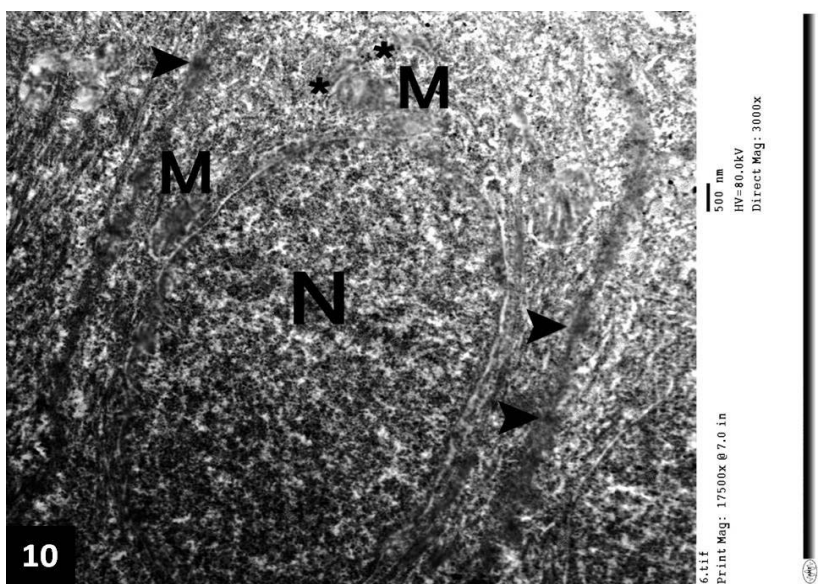

Fig. 10: A higher magnification of the previous figure showing the basal cell containing nucleus $(\mathrm{N})$, mitochondria (M), RER (asterisks). The epithelial cells are attached to each other with multiple electron-dense desmosomes (arrow heads). (TEM X 17500). 


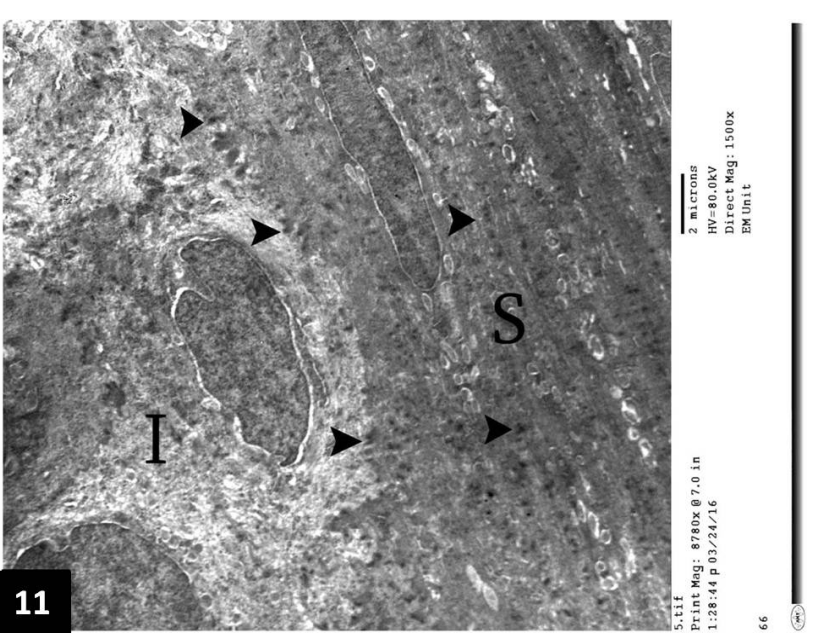

Fig. 11: An electron micrograph of rat cornea from the control group showing the superficial (S) and intermediate (I) layers of corneal epithelium. The cells are attached to each other with multiple electron-dense desmosomes (arrow heads) with narrow intercellular spaces.

(TEM X 8780).

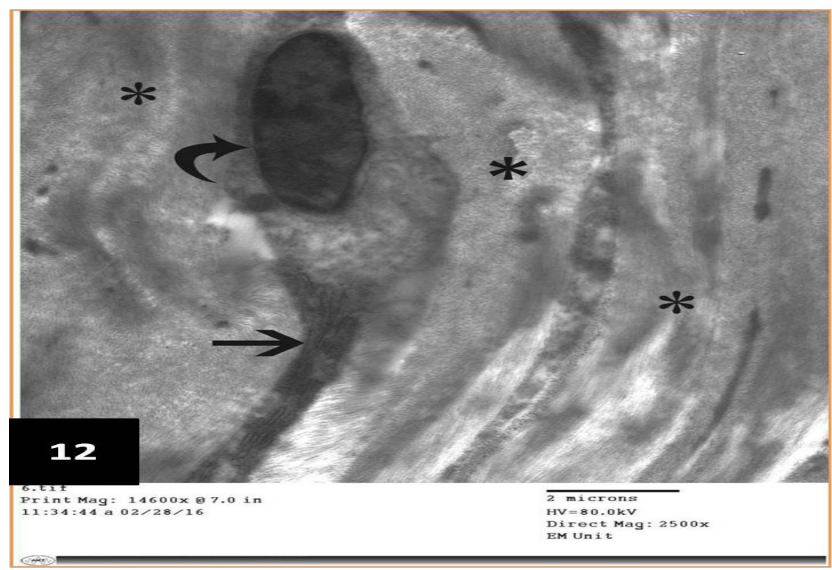

Fig. 12: An electron micrograph of rat cornea from the control group showing the stroma containing a keratocyte having electron dense oval nucleus (curved arrow), scanty cytoplasm and RER (arrow). Notice the regular arrangement of the collagen fibers (asterisks).

(TEM X 14600).

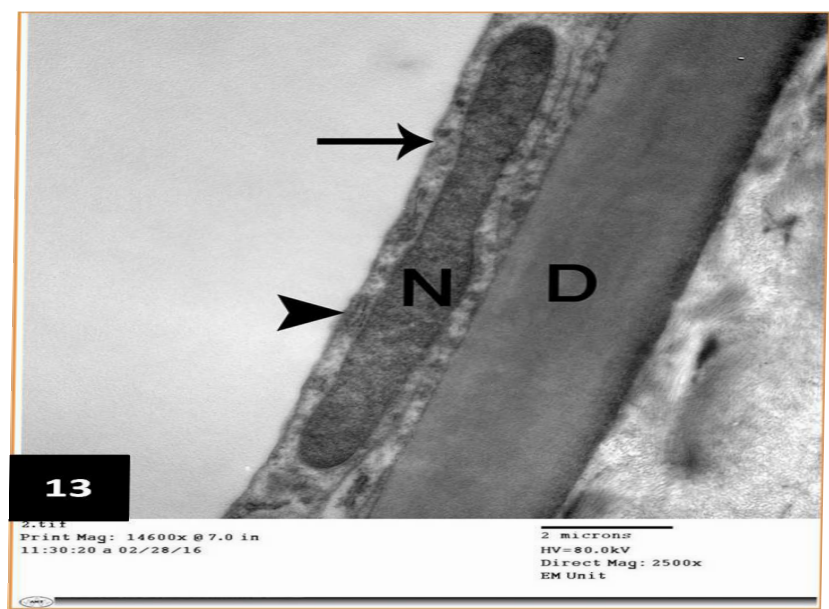

Fig. 13: An electron micrograph of rat cornea from the control group showing Descemet's membrane (D) lined by a single endothelial cell layer (arrow). Notice the presence of an electrondense elongated nucleus $(\mathrm{N})$, scanty cytoplasm and RER profile (arrow head).

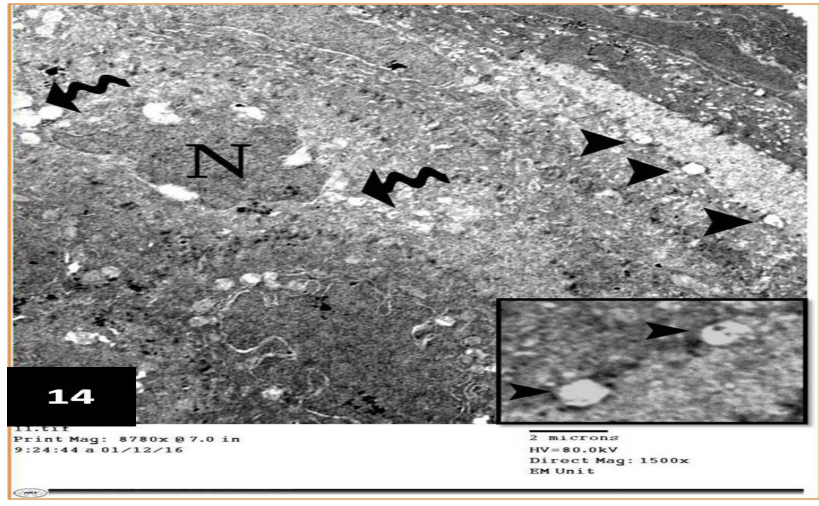

Fig. 14: An electron micrograph of rat cornea from the capecitabine-treated group (group III) showing the superficial and intermediate layers of corneal epithelium. A focal widening of the intercellular spaces (arrow heads), cytoplasmic vacuolation (wavy arrows) and dark shrunken irregular nucleus (N) are seen. The inset shows a higher magnification of a focal widening of intercellular spaces. (TEM X 8780, Inset X 17560).

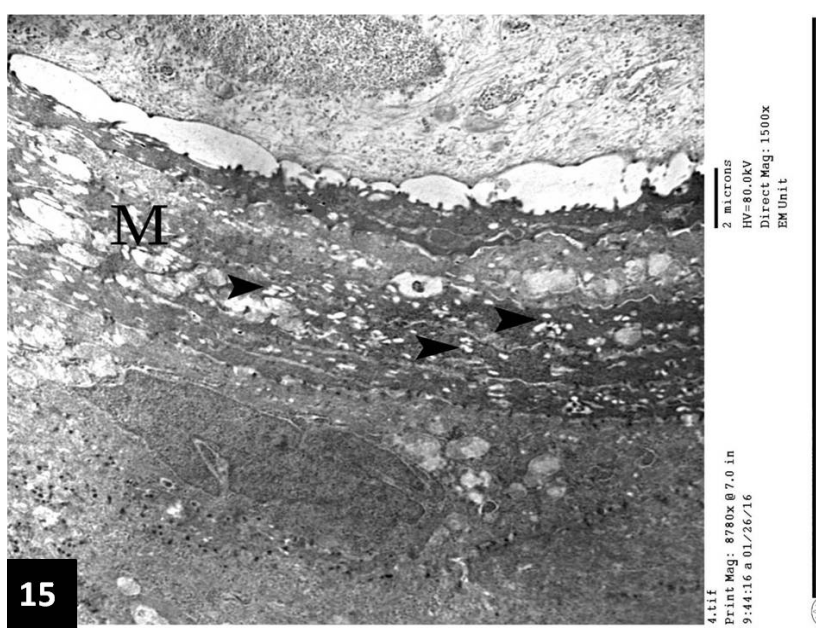

Fig. 15: An electron micrograph of rat cornea from the capecitabine-treated group (group III) showing the superficial cells of corneal epithelium containing swollen mitochondria with disrupted cristae (M) and cytoplasmic vacuolation (arrow heads).

(TEM X 8780)

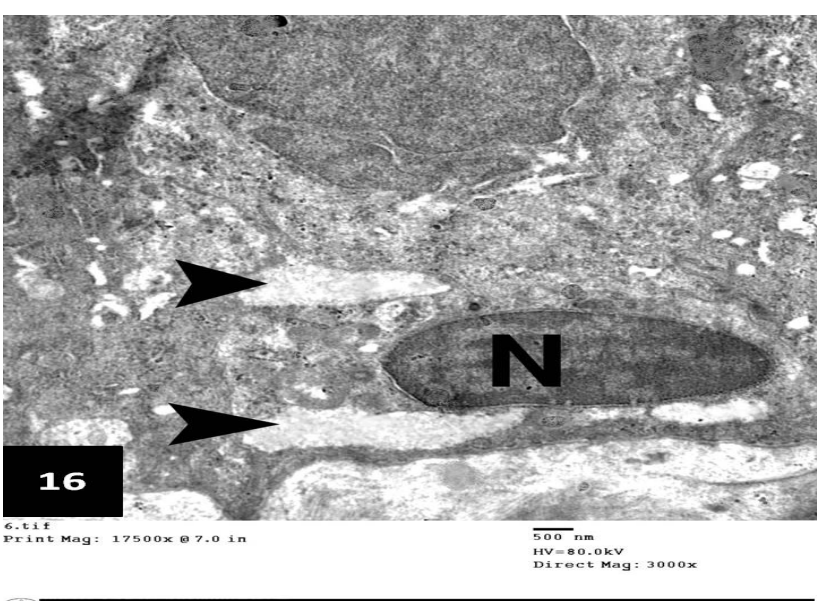

Fig. 16: An electron micrograph of rat cornea from the capecitabine-treated group (group III) showing a basal cell of corneal epithelium with multiple large cytoplasmic vacuoles (arrow heads) and shrunken hyperchromatic nucleus (N).

(TEM X 17500) 


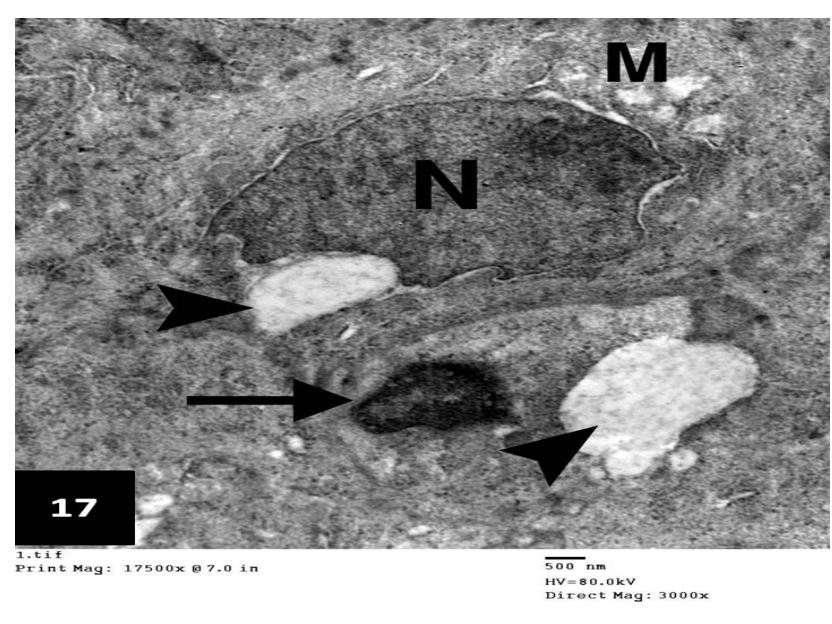

Fig. 17: An electron micrograph of rat cornea from the capecitabine-treated group (group III) showing an intermediate cell of corneal epithelium having a nucleus with irregular outlines $(\mathrm{N})$ containing large cytoplasmic vacuole (arrow heads). Other intermediate cell having a large cytoplasmic vacuole and shrunken hyperchromatic nucleus with irregular outlines can be seen. (TEM X 17500)

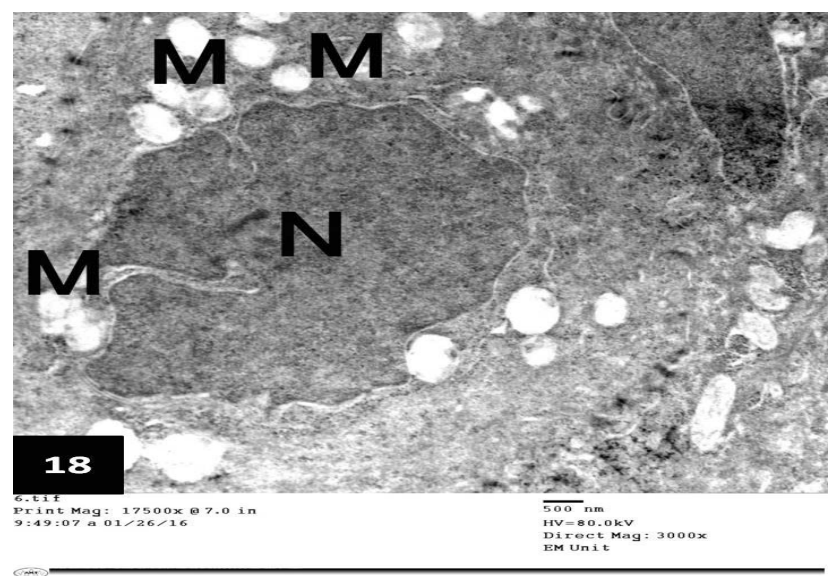

Fig. 18: An electron micrograph of rat cornea from the capecitabine-treated group (group III) showing an intermediate cell of corneal epithelium containing swollen mitochondria with disrupted cristae (M) and irregular nucleus (N). (TEM X 17500)

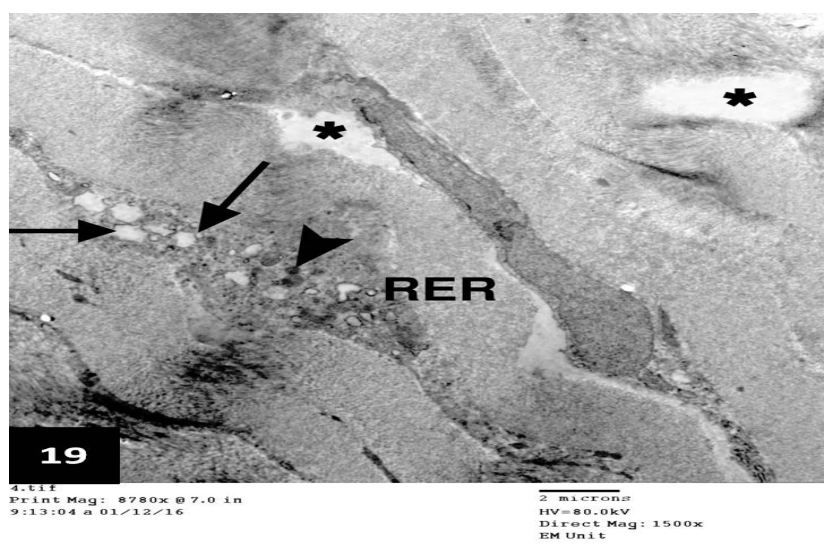

Fig. 19: An electron micrograph of rat cornea from the capecitabine-treated group (group III) showing the stroma containing a keratocyte with abundant cytoplasm containing variable-sized cytoplasmic vacuoles (arrows), lysosomes (arrow head) and dilated RER. Notice the disturbed widely separated collagen fibers (asterisks).

(TEM X 8780)

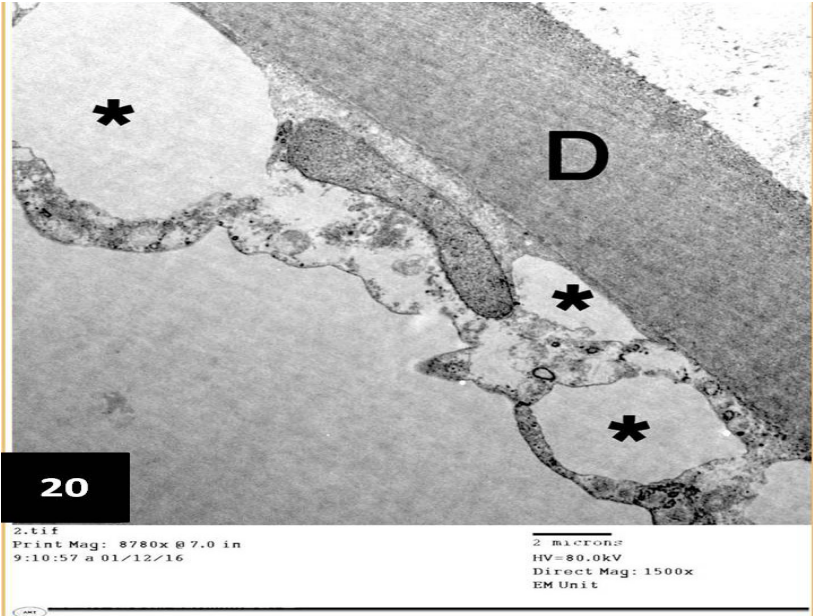

Fig. 20: An electron micrograph of rat cornea from the capecitabine-treated group (group III) showing the Descemet's endothelial layer (D) containing multiple cytoplasmic vacuoles (asterisks) in an endothelial cell.

(TEM X 8780)

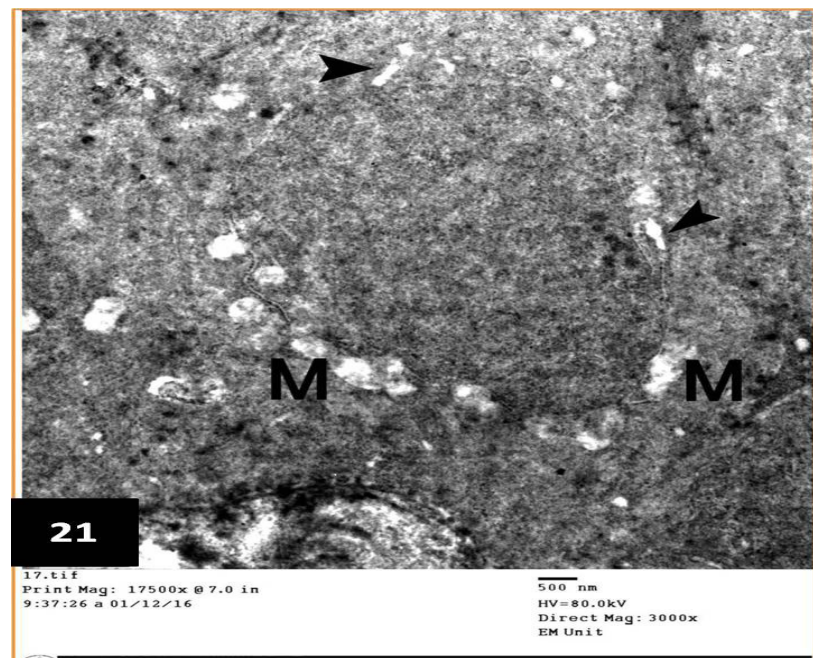

Fig. 21: An electron micrograph of rat cornea from both capecitabine and hesperidin-treated group (group IV) showing a basal epithelial cell having focal cytoplasmic vacuolation (arrow heads) and few swollen mitochondria (M).

(TEM X 17500)

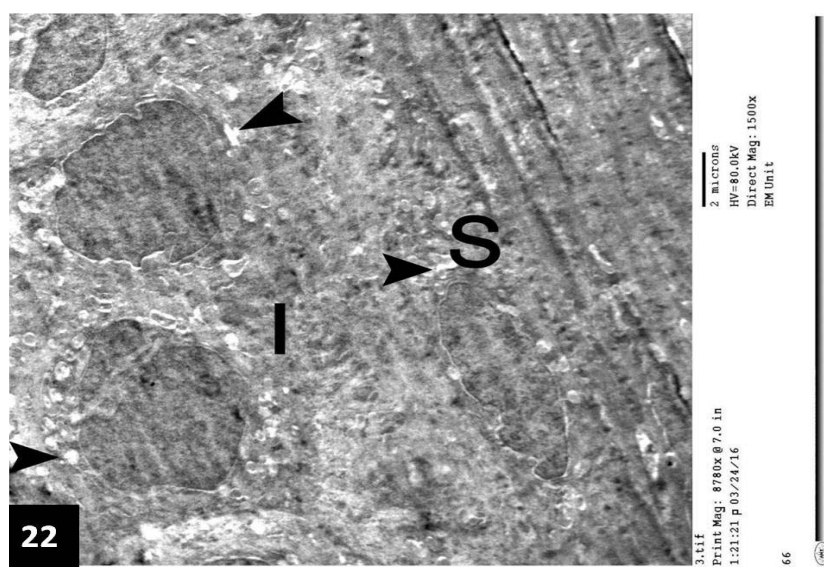

Fig. 22: An electron micrograph of rat cornea from both capecitabine and hesperidin-treated group (group IV) showing the superficial(S) and intermediate (I) epithelial cells containing focal cytoplasmic vacuolation (arrow heads).

(TEM X 8780) 


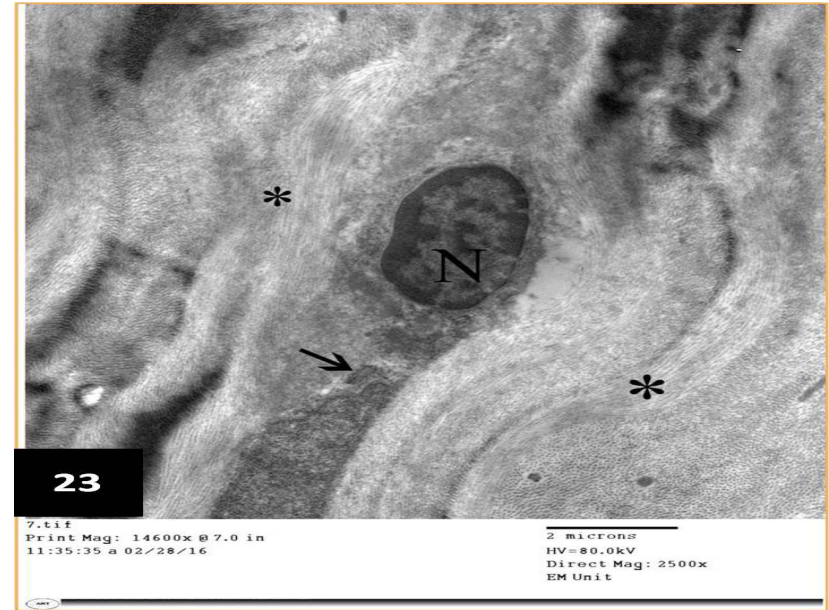

Fig. 23: An electron micrograph of rat cornea from both capecitabine and hesperidin-treated group (group IV) showing the stroma having regularly arranged collagen fibers (asterisks) and a keratocyte with electron dense oval nucleus $(\mathrm{N})$ and RER profile (arrow)

(TEM X 14600).

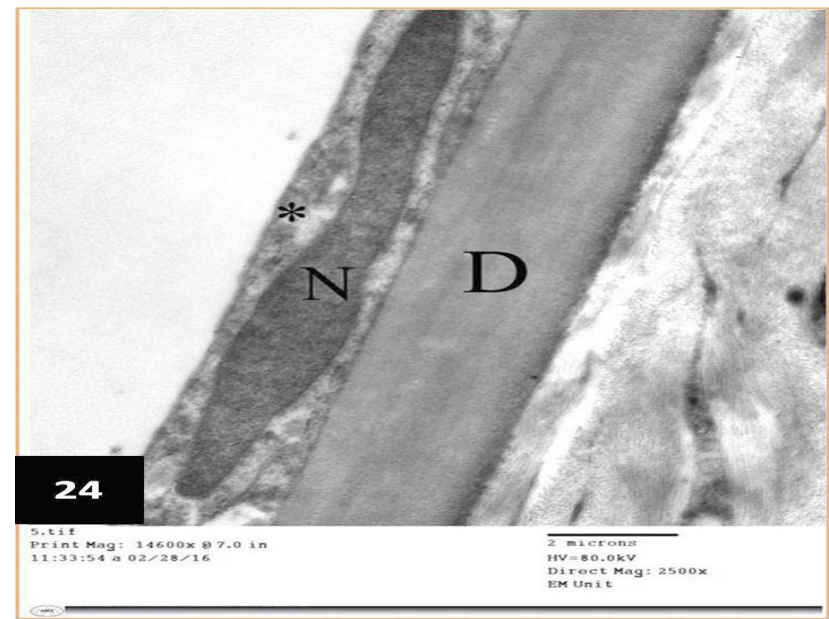

Fig. 24: An electron micrograph of rat cornea from both capecitabine and hesperidin-treated group (group IV) showing the Descemet's endothelial layer (D) containing an endothelial cell with an electron dense elongated nucleus $(\mathrm{N})$. The cytoplasm shows few small vacuoles (asterisk)

(TEM X 14600).

\section{DISCUSSION}

Chemotherapeutic drugs have a narrow therapeutic index with little difference between toxic and therapeutic effects, and the dosage needed to achieve a therapeutic response is usually toxic to different body systems and organs ${ }^{[37]}$. Many ocular disorders have been attributed to a number of anticancer drugs such as capecitabine ${ }^{[38]}$. These disorders are generally not preventable, therefore clinicians must be aware of the potential vision threatening complications caused by anticancer drugs ${ }^{[39]}$.

Many studies have reported the anti-inflammatory, antioxidant and anticarcinogenic effects of hesperidin. Moreover, hesperidin is essential for the treatment of many ocular disorders such as diabetic retinopathy and macular edema ${ }^{[40,41]}$. Accordingly, this study aimed to evaluate the potential protective role of hesperidin against the corneal toxicity caused by the anticancer drug (capecitabine) in adult male albino rat employing different histological and immunohistochemical methods.

After reviewing light and electron microscopic results in this study, it could be demonstrated that 30 days treatment with capecitabine has altered the histological structure of the cornea and caused deformations especially in the epithelial layer that appeared desquamated. The remaining epithelium was vacuolar and degenerated having pyknotic nuclei. These results were similar to those induced by N-Ethyl$\mathrm{N}-\mathrm{Nitrosourea}$ (ENU) in mice treated with $600 \mathrm{mg} /$ $\mathrm{kg}$ group for 7 days $^{[42]}$ as well as to those induced by cisplatin treatment ${ }^{[43]}$. In addition, these results were consistent with the clinical results of some authors ${ }^{[15]}$ who reported two cases having ocular irritation, decreased vision and corneal deposits associated with capecitabine use. Moreover, such corneal structural changes were consistent with the clinical findings in patients receiving other anticancer alkylating agents who complain of photophobia, foreign body sensation and tearing due to corneal epitheliopathy ${ }^{[44]}$.

The mechanism of action of capecitabine induced ocular toxicity is not wholly understood. In humans, the adverse effects of capecitabine vary greatly, and may be related to individual susceptibility, drug dosage or to enzymatic deficiencies ${ }^{[45]}$.

The present study could demonstrate corneal epithelial thinning that was confirmed by a highly significant decrease in the mean epithelial thickness in capecitabine-treated group as compared to control group. This was similar to the results of other researchers who studied the capecitabine induced corneal toxicity in $\operatorname{dogs}^{[46]}$. This epithelial thinning might be due to cellular degeneration and loss of dead cells with subsequent slow rate of cellular proliferation and regeneration ${ }^{[47]}$.

The corneal epithelium is the peripheral contact corneal region that is characterized by dynamic turnover due to continued proliferation of its basal epithelial cells which are displaced outward by the next generation of mitotic cells, and then, they are lost by desquamation ${ }^{[48]}$. The mechanisms that regulate corneal epithelial proliferation under normal physiological or pathological conditions are usually multifactorial and complex, and they are controlled by cytokine-receptor mediated events. Numerous cytokines such as epidermal growth factor activate receptors and cell signaling pathways that regulate this epithelial proliferation ${ }^{[49]}$. 
Capecitabine is a 5- flurouracil (5-FU) prodrug, therefore, 5-FU shares the ocular toxicity with capecitabine. 5-FU treatment has been found to be associated with various types of ocular toxicity, affecting mainly the corneal epithelium ${ }^{[50]}$. Previous invitro studies on the human as well as rabbit corneal epithelial cells reported that 5-FU has anti-proliferative effects $^{[51,52]}$.

Wide spaces were observed between the collagen bundles in the stroma, and this indicates corneal edema. This was accompanied by a sign of inflammation in the form of mononuclear cellular infiltration in the anterior region of the stroma. This comes in agreement with the work of other researchers ${ }^{[53]}$. The stromal inflammatory cellular infiltration was reported to be due to release of interleukin $1 \beta$ (IL1 $\beta$ ) from the injured epithelial cells. IL $1 \beta$ is a multi-potent cytokine involved in acute inflammatory response leading to infiltration by various inflammatory cells as neutrophils and macrophages ${ }^{[54]}$.

Another observation was the corneal stromal neovascularizaion. Some investigators declared that the neovascularization could be secondary to inflammation ${ }^{[55]}$. The inflammation induced stromal edema proximal to the limbus allowed blood vessel growth from the limbus to the corneal stroma ${ }^{[56]}$. Moreover, others recorded that the epithelium of the basal layers of the cornea, endothelial cells and fibroblasts were the source of angiogenic factors such as vascular endothelial growth factor (VEGF) $)^{[57]}$.

The results of the present work could demonstrate that capecitabine induced apoptosis in the corneal epithelium as demonstrated by the histological results that showed pyknotic nuclei of the corneal epithelial cells. These findings were interpreted as apoptosis by some authors ${ }^{[58]}$. In addition, the immunohistochemical results of the present work could reveal that capecitabine induced apoptosis in corneal epithelium, endothelium and keratocytes through up-regulation of p53 protein expression as indicated by the significant increase in the color intensity of p53 positive immunoreaction in capecitabine-treated group as compared to control group. This was in agreement with recent invitro studies that illustrated that 5- FU induced apoptosis in cultured corneal epithelial and endothelial cells through upregulation of apoptosis-related proteins mainly $\mathrm{p} 53$, p21 and $\mathrm{Bax}^{[59,60]}$. Other invitro study revealed that mitomycin $\mathrm{C}$ (an alkylating agent) induced apoptosis in cultured corneal keratocytes, and they attributed this to be due to the caspase cascade related to the mitochondrial pathway of apoptosis ${ }^{[61]}$.

P53 is a well known tumor suppressor protein that plays a key role in apoptosis ${ }^{[62]}$. P53 is normally synthesized in the cytoplasm and must transport into the nucleus to exert its transcriptional effect acting as a nuclear transcription factor that transactivates genes involved in apoptosis ${ }^{[63]}$. P53 can initiate apoptosis when DNA damage occurs ${ }^{[64]}$. Therefore, the significant up-regulation of p53 nuclear expression upon capecitabine administration in the present study could suggest the occurrence of DNA damage, and this may be suggested to be a mechanism of capecitabine induced corneal toxicity. This was in agreement with the results of other invitro study ${ }^{[65]}$ that demonstrated a nuclear translocation of cytoplasmic p53 in rodent corneal epilthelial cells that occurred following ultraviolet (UV) exposure. In addition, the results of the present work revealed a significant up-regulation of p53 cytoplasmic expression upon capecitabine administration. Recent papers recorded the separate cytoplasmic role of p53 in directly regulating the Bax-dependent mitochondrial pathway to apoptotic cell death, as p53 rapidly translocates to the mitochondria inducing mitochondrial outer membrane permeabilization (MOMP), and triggering the release of pro-apoptotic factors ${ }^{[66]}$. On the other hand, the present study demonstrated a moderate expression of p53 in the cytoplasm of corneal epithelium of control rats, while the stromal keratocytes as well as endothelial cells were negative for this reaction. This result was identical to previous results noted in normal corneal epithelium in rats ${ }^{[67]}$, mice ${ }^{[68]}$ and other vertebrates $^{[69]}$, and this could be attributed to the high turnover rate of the normal corneal epithelium ${ }^{[68]}$.

At the protective level, hesperidin was introduced to examine its probable role in alleviating the capecitabine induced corneal toxicity. Results from this study clearly demonstrated that hesperidin offered an evident improvement in the corneal structural changes. This could be attributed to the antioxidant capacity of hesperidin as many studies reported that hesperidin enhanced the antioxidant defense mechanisms and

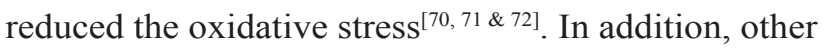
studies proved that hesperidin is a hydrogen-donor and a free-radical scavenger ${ }^{[73]}$.

In this study, pretreatment with hesperidin decreased the inflammatory cellular infiltration. This antiinflammtory effect of hesperidin has been attributed to its effect on the prostaglandin synthesis and the cyclooxygenase-2(COX-2) pathway as reported by many invitro and invivo studies ${ }^{[74]}$.

In addition, hesperidin was found to be beneficial in ameliorating the degree of apoptotic cell death. This anti-apoptotic effect of hesperidin could be probably mediated through the suppression of p53-proteins as observed from the immunohistochemical results of the current work. Though, other investigators explained the anti-apoptotic activity of hesperidin to be through upregulation of $\mathrm{Bcl}-2$ protein and suppression of Bax protein expression ${ }^{[75]}$. 
Based on the previous results, the current study suggests that hesperidin might be beneficial in minimizing the capecitabine-induced corneal structural changes in rats most probably through its anti-inflammatory and anti-apoptotic effects. Therefore, hesperidin may be a useful therapeutic agent for the patient undergoing chemotherapeutic treatment with capecitabine drug to minimize its corneal complications.

\section{CONFLICT OF INTEREST}

There are no conflicts of interest.

\section{REFERENCES}

1. Omoti $\mathrm{AE}$ and Omoti CE. Ocular toxicity of systemic anticancer chemotherapy. Pharm Pract (Granada) 2006; 4(2): 55-59.

2. Al-Tweigeri T, Nabholtz JM and Mackey JR. Ocular toxicity and cancer chemotherapy. A review. Cancer 1996; 78(7): 1359- 73

3. Li J, Tripathi RC and Tripathi BJ. Drug-induced ocular disorders. Drug Saf. 2008; 31(2): 127- 141.

4. Moorthy RS and Valluri S. Ocular toxicity associated with systemic drug therapy. Curr Opin Ophthalmol 1999; 10(6): 438-46.

5. Schmid KE, Kornek GV, Scheithauer W and Binder S. Update on ocular complications of systemic cancer chemotherapy. Surv Ophthalmol 2006; 51: 19-40.

6. Gianni L, Panzini I, Li S, Gilber RD, Collins J, Holmberg SB, Crivellari D, Castiglione-Gertsch M, Golghirsch A, Coates AS and Ravaioli A. Ocular Toxicity during adjuvant chemoendocrine therapy for early breast cancer. Cancer 2006; 106 (3):505-13.

7. Midgley R and Kerr DJ. Capecitabine: have we got the dose right? Nat Clin Pract Oncol 2009; 6(1):17-24.

8. Shindoh $\mathrm{H}$, Nakano $\mathrm{K}$, Yoshida $\mathrm{T}$ and Ishigai $\mathrm{M}$. Comparison of in vitro metabolic conversion of capecitabine to 5-fluorouracil in rats, mice, monkey and humans. toxicological implications. J Toxicol Sci 2011; 36(4):411-422.

9. Cats A. New developments in systemic chemotherapy in advanced colorectal cancer. Scand J Gastroenterol 2003; 239(Suppl):78-86.

10. Schull B, Scheithauer W and Kornek GV. Capecitabine as salvage therapy for a breast cancer patient with extensive liver metastases and associated impairment of liver function. Onkologie 2003; 26:578-80.
11. Courtin A, Richards FM, Bapiro TE, Bramhall JL, Neesse A and Cook N. Anti-tumor efficacy of capecitabine in a genetically engineered mouse model of pancreatic cancer. PLOS ONE 2013; 8(6): e 67330.

12. Hoesly FJ, Baker SG, Gunawardane ND and Cotliar JA. Capecitabine-induced hand-foot syndrome complicated by pseudomonal superinfection resulting in bacterial sepsis and death. Arch Dermatol 2011; 147(12):1418-1423.

13. Van Pelt-Sprangers MJM, Geijteman ECT, Alsma J, Boere IA, Mathijssen RHJ and Schuit SCE. Oromandibular dystonia: a serious side effect of capecitabine.BMC Cancer 2015; 15:115.

14. Cortes J, Hudgens S, Twelves C, Perez EA, Awada A, Yelle L, McCutcheon S, Kaufman PA, Forsythe A and Velikova G. Health-related quality of life in patients with locally advanced or metastatic breast cancer treated with eribulin mesylate or capecitabine in an open-label randomized phase 3 trial. Breast Cancer Res Treat 2015; 154(3):509-20.

15. Waikhom B, Fraunfelder FT and Henner WD. Severe ocular irritation and corneal depositsassociated with capecitabine use. N Engl J Med 2000; 343: 740-741.

16. Kara S,Gencer B, Karaca T, Tufan HA, Arikan S,Ersan I, Karaboga I, and Hanci V. Protective effect of hesperetin and naringenin against apoptosis in ischemia/reperfusion-induced retinal injury in rats. Sci World J 2014; 2014:797824.

17. Bigoniya $\mathrm{P}$ and Singh $\mathrm{K}$. Ulcer protective potential of standardized hesperidin, a citrus flavonoid isolated from citrus sinensis. Rev Bras Farma 2014; 24: 330-340.

18. Jain DP and Somani RS. Antioxidant potential of hesperidin protects gentamicin induced nephrotoxicity in experimental rats. Austin $\mathrm{J}$ Pharmacol Ther 2015; 3(2): 1071.

19. Khan MHA and Parvez S. Hesperidin ameliorates heavy metal induced toxicity mediated by oxidative stress in brain of Wistar rats. J Trace Elem Med Biol 2015; 23 (31): 53-60.

20. Lee HJ, Lee WJ, Chang SE and Lee G. Hesperidin, A popular antioxidant inhibits melanogenesis via Erk1/2 mediated MITF degradation. Int $\mathrm{J}$ Mol Sci 2015; 16: 18384-18395.

21. Abuelsaad AS, Mohamed I, Allam G and Al-Solumani AA. Antimicrobial and immunomodulating activities of hesperidin and ellagic acid against diarrheic Aeromonas hydrophila in a murine model. Life Sci 2013; 93(20): 714-22. 
22. Jagadeesan $G$ and Bharathi E. In vivo restoration of hepatic and nephro protective potential of hesperidin and ellagic acid against mercuric chloride intoxicated rats. Biomedicine \& Aging Pathology 2014; 4: 219-222.

23. Siddiqi A1, Nafees $\mathrm{S}$, Rashid $\mathrm{S}$, Sultana $\mathrm{S}$ and Saidullah B. Hesperidin ameliorates trichloroethyleneinduced nephrotoxicity by abrogation of oxidative stress and apoptosis in wistar rats. Mol Cell Biochem 2015; 406(1-2): 9-20.

24. Hozayen WG and Abou Seif HS. Protective effects of ruitn and / or hesperidin against doxorubicin-induced hepatotoxicity. International Journal of Clinical Nutrition 2014; 2(1): 11-17.

25. AcipayamC, Bayram I, Daglioglu K, Doran F, Yilmaz S, SezginG, Ateş BT, OzkanA and Tanyeli A.The protective effect of hesperidin on methotrexateinduced intestinal epithelial damage in rats: An Experimental Study. Med Princ Pract 2014; 23:45-52.

26. Omar HA, Mohameda WR, Arafa EA, Shehata BA, El Sherbiny GA, Arab HH and Elgendy AAM. Hesperidin alleviates cisplatin-induced hepatotoxicity in rats without inhibiting its antitumor activity. Pharmacological Reports 2016; 68: 349-356.

27. Manikandan $\mathrm{R}$ and Arumugam M. Anticataractogenic effect of hesperidin in galactose-induced cataractogenesis in Wistar rats. World $\mathrm{J}$ Ophthalmol 2016; 6(1): 1-9.

28. Kumar P and Kumar A. Protective effect of hesperidin and naringin against 3-nitropropionic acid induced Huntington's like symptoms in rats: possible role of nitric oxide. Behav Brain Res 2010; 206: 38-46.

29. Raza SS, Khan MM, Ahmad A, Ashafaq M, Khuwaja G, Tabassum R, Javed H, Siddiqui MS, Safhi MM and Islam F. Hesperidin ameliorates functional and histological outcome and reduces neuroinflammation in experimental stroke. Brain Res 2011; 1420: 93-105.

30. Kamisli S, Ciftci O, Kaya K, Cetin A, Kamisli O and Ozcan C. Hesperidin protects brain and sciatic nerve tissues against cisplatin-induced oxidative, histological and electromyographical side effects in rats. Toxicol Ind Health 2015; 31(9):841-51.

31. Paget GE and Barnes JM. Evaluation of drug activities. Toxicity tests. Chapter 5, 1964; 135-166.

32. 32- Gaertner D.J., Hallman T.M., Hankenson F.C., Batchelder M.A. Anesthesia and Analgesia for Laboratory rodents In: Fish RE, Danneman PJ, Brown m, Karas AZ editors Anesthesia and Analgesia in Laboratory Animals, 2nd edition. London (UK) Academic Press 2008; pp 239-297.

33. Bancroft JD and Gamble M. Theory and practice of histological techniques. 6th edition, Elsevier health science. 2008; 126-127.

34. Ramos-Vara JA, Kiupel M, Baszler T, Bliven L, Brodersen B, Chelack B, West K, Czub S, Del Piero F, Dial S, Ehrhart EJ, Graham T, Manning L, Paulsen D and Valli VE. Suggested guidelines for immunohistochemical techniques in veterinary diagnostic laboratories. J Vet Diagn Invest 2008; 20: 393-413.

35. Bozzola JJ and Russell LD. Electron microscopy: principles and techniques for biologists, 2nd edition, Jones and Bartlett Publishers. 1999; 100-124.

36. Dawson-Saunders B and Trapp R. Basic and clinical biostatics. 3rd ed., Lang Medical Book, McGrow Hill Medical Publishing Division. 2001; 161-218.

37. Kirthi C, Afzal A, Reddy M, Ali SA, Yerramill A and Sharma S. A study on the adverse effects of anticancer drugs in an oncology center of a tertiary care hospital, Int $\mathrm{J}$ Pharmacy Pharmaceutical Sci 2014; 6(2): 580-583.

38. Singh $\mathrm{P}$ and Singh A. Ocular adverse effects of anti-cancer chemotherapy and targeted therapy. J Can Therap Res 2012; http://www.hoajonline.com / journals /pdf/2049 -7962-1- 5 .

39. Kashmiri ZN and Sastry MS. Ocular Toxicity after an antineoplastic drug cyclophosphamide in male rat Rattus Norvegicus. International Journal of Research Studies in Biosciences (IJRSB) 2015; 3(1): 75-77.

40. Majumdar $\mathrm{S}$ and Srirangam R. Potential of the bioflavonoids in the prevention/treatment of ocular disorders. J Pharm Pharmacol. 2010; 62(8):951-65.

41. Shi X, Liao S, Mi H, Guo C, Qi D, Li F, Zhang C and Yang Z. Hesperidin prevents retinal and plasma abnormalities in streptozotocin-induced diabetic rats. Molecules 2012; 17: 12868-12881.

42. Yoshizawa K, SasakT, Kuro M, Miki M, Kimura A, Uehara N, Yuri T and Tsubura A. Corneal damage induced in adult mice by a single intraperitoneal injection of N-Ethyl-N-Nitrosourea. In Vivo 2011; 25: 609-16.

43. Polat N, Ciftci O, Cetin A and Yılmaz T. Toxic effects of systemic cisplatin on rat eyes and the protective effect of hesperidin against this toxicity. Cutan Ocul Toxicol 2016; 35(1):1-7. 
44. Van Meter WS. Central corneal opacification resulting from recent chemotherapy in corneal donors. Trans Am Ophthalmol Soc. 2007; 105: 207-12.

45. Reigner $\mathrm{B}$, Blesch $\mathrm{K}$ and Weidekamm E. Clinical pharmacokinetics of capecitabine. Clin Pharmacokinet 2001; 40:85-104.

46. Zarfoss M, Bentley E, Milovancev M, Schmiedt C, Dubielzig R and McAnulty J. Histopathologic evidence of capecitabine corneal toxicity in dogs. Vet Pathol 2007; 44(5):700-2.

47. Haaskjold E, Olsen WM, Bjerknes R and Kravik K. Early cell kinetic effects of a single dose of narrowbanded ultraviolet B irradiation on the rat corneal epithelium. Photochem.Photobiol 1993; 57(4):663-66.

48. Pellegrini G, Rama P, Mavilio F and Luca M.D. Epithelial stem cells on corneal regeneration and epidermal gene therapy. J Pathol 2009; 217: 217-28.

49. Reinach PS, Pokorny KS. The corneal epithelium: clinical relevance of cytokine-mediated responses to maintenance of corneal health. Arq Bras Oftalmol. 2008; 71(6): 80-6.

50. Lattanzio FA Jr, Sheppard JD Jr, Allen RC, Baynham $S$, Samuel $P$ and Samudre S. Do injections of 5-fluorouracil after trabeculectomy have toxic effects on the anterior segment? J Ocul Pharmacol Ther 2005; 21:223-235.

51. Huhtala A, Tahti H, Salminen L and Uusitalo H. Evaluation of adverse ocular effects of 5-fluorouracil by using human corneal epithelial cell cultures. J Toxicol Cutan Ocul Toxicol 2002; 21:283-292.

52. Botti RE, Lazarus HM, Imperia PS and Lass JH. Cytotoxicity of antineoplastic agents on rabbit corneal epithelium in vitro. J Toxicol Cutan Ocul Toxicol 1987; 6:79-87.

53. AL-Gebaly AS. Ameliorative role of jambolan against ocular toxicities of anticancer drug capecitabine in male rats. Int J Curr Res Aca Rev 2015; 3(1): 281-289.

54. Wang Z, Handa JT, Green WR, Stark WJ, Weinberg $\mathrm{RS}$ and Jun AS. Advanced glycation end products and receptors in Fuchs' dystrophy corneas undergoing Descemet's stripping with endothelial keratoplasty. Ophthalmology 2007; 114(8):1453-1460.

55. Clements JL and Dana R. Inflammatory corneal neovascularization: etiopathogenesis. Semin Ophthalmol. 2011 Jul-Sep; 26(4-5):235-45.

56. Scheufler KM. Tissue oxygenation and capacity to deliver $\mathrm{O} 2$ do the two go together? Transfus Apher Sci 2004; 31:45-54.
57. Pauloin T, Dutot M, Joly F, Warnet JM, Rat P. High molecular weight hyaluronan decreases UVB-induced apoptosis and inflammation in human epithelial corneal cells. Mol Vision 2009; 15:577-583.

58. Kerr JFR, Winterford CM and Harmon BW. Apoptosis: its significance in cancer and cancer therapy. Cancer 1994; $73: 2013-26$.

59. Wu KY, Lai YH, Yang YC, Wu WC and Hong SJ. 5-Fluorouracil-induced apoptosis changes in cultured corneal epithelial cells. J Ocul Pharmacol Ther 2016; 32(3):155-62.

60. Hong SJ, Wu WC, Lai YH and Wu KY. Mechanism of 5-fluorouracil-induced apoptosis on cultured corneal endothelial Cells. Open Journal of Apoptosis 2014; 3: 5-15.

61. Kim TI, Tchah H, Lee SA, Sung K, Cho BJ, Kook MS. Apoptosis in keratocytes caused by mitomycin C. Invest Ophthalmol Vis Sci. 2003; 44(5):1912-7.

62. Leigh-Brown S, Enriquez JA and Odom DT. Nuclear transcription factors in mammalian mitochondria. Genome Biol. 2010; 11(7):215.

63. O'Brate A and Giannakakou P. The importance of p53 location: nuclear or cytoplasmic zip code? Drug Resist Updat 2003; 6(6):313-22.

64. Mraz M, Malinova K, Kotaskova J, Pavlova S, Tichy B, Malcikova J, Stano Kozubik K, Smardova J, Brychtova Y, Doubek M, Trbusek M, Mayer J and Pospisilova S. MiR-34a, miR-29c and miR17-p are downregulated in CLL patients with TP53 abnormalities. Leukemia 2009; 23(6):1159-63.

65. Tendler Y, Pokroy R, Panshin A, Weisinger G. P53 protein subcellular localization and apoptosis in rodent corneal epithelium cell culture following ultraviolet irradiation. Int J Mol Med. 2013; 31(3):540-6.

66. Wang DB, Kinoshita C, Kinoshita Y, and Morrison RS. P53 and mitochondrial function in neurons. Biochim Biophys Acta 2014; 1842(8): 1186-1197.

67. Tendler Y, Weisinger G, Coleman R, Diamond E, Lischinsky S, Kerner H, Rotter V, Zinder O. Tissuespecific p53 expression in the nervous system. Brain Res Mol Brain Res. 1999; 72(1):40-6.

68. Pokroy R, Tendler Y, Pollack A, Zinder O, Weisinger G. p53 expression in the normal murine eye. Invest Ophthalmol Vis Sci. 2002; 43(6):1736-41.

69. Tendler Y, Panshin A, Weisinger G, Zinder O. Identification of cytoplasmic p53 protein 
in corneal epithelium of vertebrates. Exp Eye Res. 2006; 82(4):674-81.

70. Jeong JM, Choi CH, Kang SK, Lee IH, Lee JY and Jung H.. Antioxidant and chemosensitizing effects of flavonoids with hydroxy and/or methoxy groups and structure-activity relationship. J Pharm Pharm Sci 2007; 10, 537-546.

71. Loguercio $\mathrm{C}$ and Federico A. Oxidative stress in viral and alcoholic hepatitis. Free Radic Biol Med 2003; 34(1): 1-10.

72. Tirkey N, Pilkhwal S, Kuhad A and Chopra K. Hesperidin, a citrus bioflavonoid, decreases the oxidative stress produced by carbon tetrachloride in rat liver and kidney. BMC Pharmacol 2005; 5: 2.
73. Kaur G, Tirkey N and Chopra K. Beneficial effect of hesperidin on lipopolysaccharide-induced hepatotoxicity. Toxicology 2006; 226(2-3): 152-160.

74. Parhiz H, Roohbakhsh A, Soltani F, Rezaee R and Iranshahi M. Antioxidant and anti-inflammatory properties of the citrus flavonoids hesperidin and hesperetin: an updated review of their molecular mechanisms and experimental models. Phytother Res 2015; 29(3):323-31.

75. Agrawal YO, Sharma PK, Shrivastava B, Ojha S, Upadhya HM, Arya DS and Goyal SN. Hesperidin produces cardioprotective activity via PPAR- $\gamma$ pathway in ischemic heart disease model in diabetic rats. PLoS One 2014; 9(11): e111212. 


\section{الملخص العربى}

\section{الاور الوقائى المحتمل للههبيزيدين ضد سمية القرنية الناجمة عن الكابيسيتابين

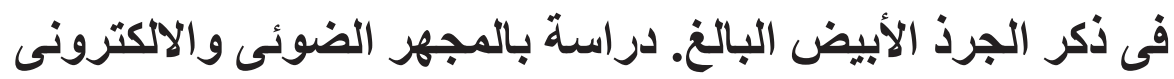 \\ ولاء محمد علوان و أميرة عدلى كساب}

\section{قسم الهستولوجيا ـ كلية الطب - جامعة طنطا}

مقدمة: عقار الكابيسيتابين هو علاج كيميائي مستخدم على نطاق واسع لعلاج الأورام الخبيثة،الا انه يسبب اضطر ابات للعين. الهسبيريدين هو مركب طبيعى مشتق اساسا من الحمضيات ويتمتع بمجموعة واسعة من الأنشطة الدوائية ودور مقترح في مكافحة الكثير من أمر اض العين.

الهدف من العمل: تهدف هذه الدراسة إلى تقييم الدور الوقائى الهحتمل للهيبيريدين ضد سمية القرنية الناجمة عن الكابيسيتابين فى ذكر الجرذ الأبيض البالغ. مواد و طرق البحث: تم تقسيم ستة وثلاثون من ذكور الجرذان البيضاء إلى أربع مجموعات منساوية. المجموعة الضابطة، المجموعة التي عولجت بالهسبيريدين (50 ملجم / كجم)، مجموعة معالجة بعقار كابيسيتابين (40 ملجم / كجم)، و المجموعة التي عولجت بكلاهما. تم اعطاء الحيو انات هذه الجر عات بالفم مرة واحدة بو ميا لمدة شهر . تم تجهيز عينات من القرنية للفحص p53. بالمجر الضوئى والمجهر الإلكتروني. كما تم عمل صبغات هستوكيميائية مناعية بإستخدام أجسام ضده ئدئ النتائج: أظهرت عينات من الحيو انات المعالجة بعقار كابيسيتابين انخفاض ذو دلالة إحصائية فى سمك الغثاء الطلائى. كما ظهرت تجاويف في السيتوبلازم وبعض التغيرات فى انوية الخلايا الطلائية. وقد أظهر نسيج القرنية الضام ألياف الكو لاجين غير منتظمة مع وجود مسافات واسعة بينها ، كما ظهرت بعض الخلايا وحيدة النواة مع وجود أوعية دموية جديدة، وعلى مستوى التركيب الدقيق فقد لوحظ وجود اتساع بؤرى للمسافات بين الخلايا وفقدان جزئى للتقاطع الديزوموزمى وتورم للميتوكوندريا. وقد أظهرت الدر اسة الهستوكيميائية المناعية زيادة ذات دلالة إحصائية في التفاعل المناعى p53. في المقابل، فقد لوحظ تغير ات طفيفة فى الجرذان التى عولجت بالتز امن بكل من عقار كابيسيتابين و هسبيريدين مع وجود زيادة ليست ذات دلالة إحصائية فى التفاعل المناعي. الاستتتاج: عقار كابيسيتابين تسبب فى حدوث تغيرات تركيبية فى قرنية الجرذ الأبيض التي يمكن أن تتحسن بالعلاج المصاحب بالأهبيريدين. 